fundamental work leading to the development of the so-called down-jet furnace. In all normal fuel beds, a considerable amount of carbon monoxide is emitted from the top surface, and thus secondary air must be fed into the combustion chamber to burn the fuel completely. The reason for the production of carbon monoxide is the practical limitation that the bed must be deep enough to prevent any serious amount of channelling, whereby oxygen is not then completely consumed. Carbon dioxide produced in the initial stages of combustion is therefore inevitably reduced to carbon monoxide, which must be re-oxidized. The maximum attainable temperature from a fuel is therefore never attained. In the down-jet furnace, the air stream is directed downwards to the fuel bed, and in this way the depth of the combustion layer is kopt at a minimum, with the result that an intensely hot flame is produced and the carbon dioxide content of the issuing gas is high. The paper described the various difficulties overcome in putting the principles to work in an actual furnace. A novel development of this type is bound to open wide fields of researches connected with chemical processes at temperatures hitherto unattainable by conventional furnaces burning carbonaceous fuels in the presence of air.

H. W. Melville.

\section{NATIONAL FLOUR (80 PER CENT EXTRACTION) AND BREAD IN BRITAIN}

\section{Eighth Report from the Scientific Adviser's Division, Ministry of Food}

$\mathrm{T}^{\mathrm{H}}$

HE present report covers the two periods 1 June 18-August 11 and October 8-December 15, 1945 ; during this time, 4,334 samples of National 80 per cent flour were examined. Examination of the samples followed the same lines as described in previous reports on National flour (cf. ref. 1) ; individual samples were examined in respect of colour index (bran speck contamination), granularity, baking quality, vitamin $\mathrm{B}_{1}$ and creta proparata content, while ash, fibre, creta, iron, nitrogen and nicotinic acid were determined on fortnightly composite samples in which the individual samples were blended according to the size of the mill by which they had been manufactured. (Riboflavin figures have not been included in this survey partly because the microbiological technique, which is the method in general use in these laboratories, has not given consistent results and also because satisfactory agreement with biological methods has not yet been established. The microbiological estimation of nicotinic acid, on the other hand, appears to be generally satisfactory.) National average figures on sample and capacity bases were calculated from results obtained on these composite samples. Data concerning the average composition of the grist used in milling the flour and of the quantities and kind of imported flour admixed were compiled from the information accompanying the survey samples, sent by the millers.

\section{Composition of the Grist and Average Protein Content}

Since the end of the period covered by the previous report on National flour ${ }^{1}$, the proportion of homegrown wheat in the grist has decreased to half its former value. A temporary increase in the amount of Plate wheat was followed by a considerable increase in the proportion of Manitoba wheat, which now averages 77 per cent of the total grist. The fluctuations in protein content of the grist closely follow the changes in the proportion of Manitoba wheat, as shown by the data in Table 1 :

TABle 1. Average composition OF Grist (CAPACITY BaSIS) AND PROTEIN CONTENT OF SAMPLES ANALYSED.

\begin{tabular}{|c|c|c|c|c|}
\hline \multirow[b]{2}{*}{$\begin{array}{l}\text { Fortnight } \\
\text { beginning }\end{array}$} & \multicolumn{3}{|c|}{ Average composition of grist } & \multirow{2}{*}{$\begin{array}{l}\text { A verage pro- } \\
\text { tcin content, } \\
\text { per cent } \\
(=\mathrm{N} \times 5 \cdot 7)\end{array}$} \\
\hline & $\begin{array}{l}\text { Manitoba } \\
\text { (per cent) }\end{array}$ & $\begin{array}{l}\text { Home- } \\
\text { grown } \\
\text { (per cent) }\end{array}$ & $\begin{array}{c}\text { Plate } \\
\text { and other } \\
\text { (per cent) }\end{array}$ & \\
\hline Jan. 22 & $58 \cdot 5$ & $35 \cdot 4$ & $6 \cdot 1 *$ & $11 \cdot 8$ \\
\hline April 2 & $61 \cdot 2$ & $35 \cdot 7$ & $3 \cdot 1$ & $11 \cdot 9$ \\
\hline June 18 & $56 \cdot 7$ & $37 \cdot 1$ & $6 \cdot 2$ & $11 \cdot 8$ \\
\hline July 2 & $56 \cdot 3$ & $36 \cdot 6$ & $7 \cdot \overline{1}$ & - \\
\hline July 16 & $52 \cdot 4$ & $38 \cdot 3$ & $9 \cdot 3$ & $11 \cdot 6$ \\
\hline July 30 & $53 \cdot 8$ & $37 \cdot 4$ & 8.8 & _- \\
\hline Oct. 8 & $67 \cdot 1$ & $28: 3$ & $4 \cdot 6$ & $12 \cdot 0$ \\
\hline Oct. 22 & $74 \cdot 4$ & $21 \cdot 8$ & $3 \cdot 8$ & - \\
\hline Nov. 5 & $76 \cdot 8$ & $18 \cdot 7$ & $4 \cdot 5$ & 一 \\
\hline Nov. 19 & $76 \cdot 0$ & $18 \cdot 8$ & $5 \cdot 2$ & - \\
\hline Dec. 3 & $77 \cdot 3$ & $18 \cdot 8$ & $3 \cdot 9$ & $12 \cdot 4$ \\
\hline
\end{tabular}

* Including 0.2 per cent of ryo and barles.

\section{Addition of Imported White Flour}

Approximately 15 per cent of imported white flour was added at the mill to all National flour manufactured during the period June 18-August 11. Thereafter the average rate of addition was reduced to 5 per cent. The source of this imported flour was as shown in Table 2.

TANLE 2. SOURCE OF IMPORTED WHITE FIOUR.

\begin{tabular}{|c|c|c|c|c|c|}
\hline \multirow[b]{2}{*}{$\begin{array}{l}\text { Fortmight } \\
\text { beginning }\end{array}$} & \multicolumn{4}{|c|}{ Average rate of addition } & \multirow{2}{*}{$\begin{array}{l}\text { Total } \\
\text { (per } \\
\text { cent) }\end{array}$} \\
\hline & $\begin{array}{l}\text { American } \\
\text { (per } \\
\text { cent) }\end{array}$ & $\begin{array}{l}\text { Canadian } \\
\text { (per } \\
\text { cent) }\end{array}$ & $\begin{array}{l}\text { Plate } \\
\text { (per } \\
\text { cent) }\end{array}$ & $\begin{array}{c}\text { Australian } \\
\text { (per } \\
\text { cent) }\end{array}$ & \\
\hline Jure 18 & $2 \cdot 0$ & \multicolumn{3}{|c|}{ 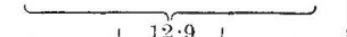 } & $14 \cdot 9$ \\
\hline July 2 & $\overline{2} \cdot 5$ & $11 \cdot 9$ & $0 \cdot 2$ & 0.4 & $15 \cdot 0$ \\
\hline July 16 & $1 \cdot 9$ & $11 \cdot 9$ & $0 \cdot 4$ & 0.7 & $14 \cdot 9$ \\
\hline July 30 & $1 \cdot 7$ & $31 \cdot 3$ & $0 \cdot 9$ & $1 \cdot 1$ & $15 \cdot 0$ \\
\hline Oct. 8 & $0 \cdot 2$ & $4 \cdot 4$ & $0 \cdot 2$ & 0.7 & $5 \cdot 5$ \\
\hline Oct. 22 & 0.1 & $4 \cdot 4$ & $0 \cdot 2$ & $0 \cdot 6$ & $5 \cdot 3$ \\
\hline Nov. 5 & $0 \cdot 4$ & $3 \cdot 9$ & $0 \cdot \overline{4}$ & $0 \cdot 8$ & $5 \cdot 5$ \\
\hline Nov. 19 & $0 \cdot 4$ & $4 \cdot 1$ & $0 . \overline{2}$ & 0.8 & $5 \cdot 5$ \\
\hline Dec. 3 & $0 \cdot 1$ & $3 \cdot 9$ & $0 \cdot 8$ & $0 \cdot 8$ & $5 \cdot 6$ \\
\hline
\end{tabular}

\section{Colour Index and Granularity}

A summary of the colour index (bran speck contamination) data is given in Table 3. The colour index value expresses the speckiness as a percentage of that of an average 85 per cent National flour (colour index value 100). A flour with a colour index value of 0 would therefore be entirely free from visible bran specks. The speckiness has shown a slight temporary increase during the period under consideration. The fineness of grinding of the flour has remained markedly constant; sifting tests on 1,010 samples examined during the last four weeks of the period show that the average percentage weight of the sample which, under standard conditions, does not pass through the No. 10 standard bolting silk is $7 \cdot 45$ per cent as compared with $7 \cdot 3$ per cent in the previous period, February 2-May 5, $1945^{1}$. The mode, or most frequently occurring value, has, however, decreased from $5 \cdot 5$ to $3 \cdot 7$ per cent, while the range of values encountered $(0-41$ per cent) is slightly wider.

\section{Vitamin $B_{1}$}

Fortnightly average values for vitamin $B_{1}$, on sample and capacity bases, together with the fre- 
TABLE 3. SUMMARY OF COLOUR INDEX (BRAN SPECKINESS) DATA.

\begin{tabular}{|c|c|c|c|c|c|c|c|c|c|}
\hline \multirow{2}{*}{ Colour Index not exceeding } & \multicolumn{9}{|c|}{ Percentage of all samples examined in weeks commeneing } \\
\hline & June 18 & July 2 & July 16 & July 30 & Oct. 8 & Oct. 22 & Nov. 5 & Nov. 19 & Dec. 3 \\
\hline 5 units & 7 & 9 & 9 & 5 & 5 & 7 & 10 & 10 & 6 \\
\hline $10 \quad$, & 29 & 30 & 24 & 21 & 19 & 31 & 32 & 40 & 34 \\
\hline $15, "$ & 55 & 51 & 42 & 40 & 42 & 52 & 53 & 56 & 59 \\
\hline $20 "$, & 68 & 67 & 67 & 58 & 67 & 68 & 70 & 75 & 75 \\
\hline 30, & 80 & 81 & 83 & 79 & 85 & 85 & 84 & 88 & 84 \\
\hline $40 \quad$, & 90 & 91 & 93 & 90 & 91 & 92 & 92 & 93 & 90 \\
\hline $\begin{array}{l}50 \\
70\end{array}$ & $\begin{array}{r}98 \\
100\end{array}$ & $\begin{array}{l}97 \\
99\end{array}$ & $\begin{array}{l}97 \\
99\end{array}$ & $\begin{array}{l}97 \\
99\end{array}$ & $\begin{array}{l}97 \\
99\end{array}$ & $\begin{array}{l}97 \\
99\end{array}$ & $\begin{array}{l}95 \\
99\end{array}$ & $\begin{array}{l}97 \\
98\end{array}$ & $\begin{array}{l}96 \\
98\end{array}$ \\
\hline Averäge Colour Index & & & & & & & & & \\
\hline Sample basis & $21 \cdot 3$ & $21 \cdot 6$ & $22 \cdot 2$ & $23 \cdot 8$ & $22 \cdot 8$ & $21 \cdot 6$ & $21 \cdot 1$ & $19 \cdot 7$ & $21: 0$ \\
\hline Capacity basis & $15 \cdot 2$ & $15 \cdot 2$ & $15 \cdot 9$ & $17 \cdot 3$ & $17 \cdot 8$ & $15 \cdot 6$ & $14 \cdot 4$ & $13 \cdot 5$ & $14 \cdot 2$ \\
\hline No. of samples examined & 243 & 233 & 232 & 232 & 245 & 246 & 247 & 248 & 259 \\
\hline
\end{tabular}

TABLE 4. SUMMaRY OF VITAMiN B DATA.

\begin{tabular}{|c|c|c|c|c|c|c|c|c|c|c|}
\hline \multirow{2}{*}{$\begin{array}{c}\left.\text { Vitamin } B_{1} \text { (I. . } / \mathrm{gm} .\right) \\
\text { not less than }\end{array}$} & \multicolumn{9}{|c|}{ Percentage of samples in fortnightly periods commencing } & \multirow{2}{*}{$\begin{array}{c}\text { Average } \\
\text { for } 18 \\
\text { weeks }\end{array}$} \\
\hline & June 18 & July 2 & July 16 & July 30 & Oct. 8 & Oct. 22 & Nov. 5 & Nov. 19 & Dec. 3 & \\
\hline $1 \cdot 0$ & 1 & 3 & 1 & 1 & 1 & 2 & 2 & 3 & 2 & 2 \\
\hline 0.95 & 2 & 6 & 1 & 2 & 4 & 4 & $\overline{3}$ & 5 & $\overline{2}$ & $\overline{3}$ \\
\hline 0.9 & 15 & 10 & 7 & 4 & 8 & 11 & 7 & 8 & 7 & 9 \\
\hline 0.85 & 26 & 19 & 14 & 9 & 19 & 23 & 23 & 23 & 16 & 20 \\
\hline 0.8 & 46 & 39 & 36 & 27 & 41 & 40 & 38 & 46 & 36 & 39 \\
\hline $0 \cdot 75$ & 70 & 62 & 55 & 59 & 65 & 61 & 64 & 63 & 58 & 62 \\
\hline 0.7 & 85 & 77 & 79 & 87 & 80 & 78 & 81 & 81 & 79 & 81 \\
\hline 0.65 & 93 & 87 & 88 & 96 & 89 & 86 & 92 & 59 & 88 & 90 \\
\hline 0.6 & 98 & 94 & 94 & 98 & 95 & 92 & 97 & 93 & 94 & 95 \\
\hline $\begin{array}{c}\text { Average } \mathbf{B}_{1} \text {, 1.U./gm. } \\
\text { Sample basis }\end{array}$ & $0 \cdot 79$ & $0 \cdot 77$ & $0 \cdot 76$ & $0 \cdot 76$ & 0.77 & $0 \cdot 77$ & $0 \cdot 77$ & $0 \cdot 77$ & $0 \cdot 76$ & $0 \cdot 77$ \\
\hline Capacity basis & 0.81 & $0 \cdot 79$ & $0 \cdot 76$ & $0 \cdot 76$ & $0 \cdot 79$ & $0 \cdot 78$ & 0.77 & $0 \cdot 78$ & 0.77 & $0 \cdot 78$ \\
\hline No. of samples analysed & 198 & 196 & 199 & 179 & 196 & 217 & 204 & 190 & 188 & 196 \\
\hline $\begin{array}{l}\text { Per cent of total capa- } \\
\text { city represented }\end{array}$ & 87 & 86 & 88 & 82 & 88 & 91 & 90 & 88 & 87 & 87 \\
\hline
\end{tabular}

TABLE 5. FIBRE, ASH, CRETA, NiCOTINIC ACID AND IRON IN NATIONAL FloUR: CAPACITx BaSIS (FROM ANALYSIS OF COMPOSITE SAMPLES).

\begin{tabular}{|c|c|c|c|c|c|c|c|c|c|c|}
\hline Fortnight commencing & June 18 & July 2 & July 16 & July 30 & Oct. 8 & Oct. 22 & Nov. 5 & Nov. 19 & Dec. 3 & $\begin{array}{c}\text { Average } \\
\text { for } 18 \\
\text { weeks }\end{array}$ \\
\hline $\begin{array}{l}\text { Fibre, per cent } \\
\text { Ash, per cent* } \\
\text { Creta, oz./sk. } \\
\text { Nicotinic acid, p.p.m. } \\
\text { Iron, p.p.m. }\end{array}$ & $\begin{array}{c}0 \cdot 23 \\
0 \cdot 72 \\
4 \cdot 6 \\
16 \cdot 8 \\
17 \cdot 0\end{array}$ & $\begin{array}{c}0 \cdot 20 \\
0 \cdot 69 \\
4 \cdot 5 \\
16 \cdot 2 \\
15 \cdot 8\end{array}$ & $\begin{array}{l}0 \cdot 17 \\
0 \cdot 67 \\
5 \cdot 5 \\
18 \cdot 0 \\
15 \cdot 9\end{array}$ & $\begin{aligned} 0 \cdot 20 \\
0 \cdot 70 \\
4 \cdot 9 \\
17 \cdot 8 \\
16 \cdot 0\end{aligned}$ & $\begin{array}{c}0 \cdot 21 \\
0 \cdot 67 \\
5 \cdot 4 \\
15 \cdot 4 \\
15 \cdot 9\end{array}$ & $\begin{array}{c}0 \cdot 19 \\
0 \cdot 66 \\
5 \cdot 2 \\
17 \cdot 0 \\
15 \cdot 3\end{array}$ & $\begin{array}{c}0 \cdot 20 \\
0 \cdot 63 \\
7 \cdot 1 \\
15 \cdot 2 \\
15 \cdot 2\end{array}$ & $\begin{array}{c}0 \cdot 17 \\
0 \cdot 66 \\
6 \cdot 9 \\
15 \cdot 7 \\
15 \cdot 9\end{array}$ & $\begin{array}{l}0 \cdot 20 \\
0 \cdot 65 \\
7 \cdot 2 \\
14 \cdot 9 \\
15 \cdot 4\end{array}$ & $\begin{array}{l}0 \cdot 20 \\
0 \cdot 67 \\
5 \cdot 7 \\
16 \cdot 3 \\
15 \cdot 8\end{array}$ \\
\hline
\end{tabular}

* Corrected for added creta. The statutory addition of $7 \mathrm{oz}$. of creta per $280 \mathrm{lb}$. sack of flour increases the ash content by $0 \cdot 12$ per cent.

quency distribution of the individual values, are shown in Table 4.

Although the National average figure for $B_{1}$ is sensibly constant, there is a fluctuation in the vitamin $B_{1}$ content of the flour produced by any particular mill ; consecutive determinations over a number of weeks showed that for 269 mills the average range of fluctuation was 0.14 r.v./gm. This may be due in part to variation in the vitamin $B_{1}$ content of the wheat.

The lowest two values were found in the periods commencing July 16 and July 30 , when the percentage of Manitoba wheat in the grist was least. Otherwise there is no correlation between vitamin $B_{1}$ content of the flour and the composition of the grist.

\section{Analysis of Fortnightly Composite Samples}

The analytical data obtained from the fortnightly composite samples are presented in Table 5. They are corrected for added white flour.

In the report of the Conference on the Post-War Loaf ${ }^{2}$, a recommendation is put forward (par. 32) that flour should contain the following minimum quantities of three token nutrients :

$$
\begin{array}{ll}
\begin{array}{c}
\text { Nutrient } \\
\text { Vitamin B }
\end{array} & \multicolumn{2}{c}{\text { Quantity }} \\
\text { Nicotinic acid } & 1.60 \text { mgm. per } 100 \mathrm{gm} . \\
\text { Iron } & 1.65,,,,,,
\end{array}
$$

On referring to Tables 4 and 5 above, it will be noted that the National average figures found for vitamin $B_{1}$, nicotinic acid and iron in the period under survey have been $0.234,1.66$ and $1.58 \mathrm{mgm}$. per $100 \mathrm{gm}$. respectively.

\section{Quality of Bread}

Loaves baked from National Flour Survey Samples.

During the period under consideration, 448 samples of flour were baked under ideal conditions in the laboratory and the resulting loaves judged for volume, colour and quality of crumb, and were classified as follows :

$\begin{array}{ccc}\text { Quality of bread } & \text { Number of loaves } & \text { Per cent of total } \\ \text { Good } & 322 & 71.8 \\ \text { Fair-good } & 70 & 15.6 \\ \text { Fair } & 43 & 9 \cdot 6 \\ \text { Poor } & 13 & 2.9\end{array}$

Survey of Commercially Baked Bread

During the period May 7-August 31 (when this commercial bread survey ended) 1,016 samples of bread purchased from bakers in different parts of Great Britain have been examined and judged (commercial standards) with the following results : Quality of bread Number of loaves Per cent of total $\begin{array}{lrr}\text { Good } & 116 & 11 \cdot 4 \\ \text { Fair-good } & 497 & 49 \cdot 0 \\ \text { Fair } & 304 & 29 \cdot 9 \\ \text { Poor } & 99 & 9 \cdot 7\end{array}$

This work has been carried out at the Cereals Research Station, Ministry of Food, St. Albans.

${ }^{1}$ Nature, 155, 717 (1945).

${ }^{2}$ Report of the Conference on the Post-War Loaf, 1945. Cmd. 6701. (I.ondon: H.M. Stationery Office, 1945.) 